\title{
Control of testicular vasomotion by testosterone and tubular factors in rats
}

\author{
O. Collin ${ }^{1}$, A. Bergh ${ }^{1,2 *}$, J-E. Damber ${ }^{3,4}$ and A. Widmark ${ }^{5}$ \\ Departments of ${ }^{1}$ Anatomy, ${ }^{2}$ Pathology, and ${ }^{3}$ Urology and Andrology, ${ }^{4}$ Physiology, ${ }^{5}$ Oncology, \\ University of Umeå, Umeå, Sweden
}

\begin{abstract}
Testicular vasomotion (rhythmical variations in testicular blood flow) was studied in adult rats using laser Doppler flowmetry. Vasomotion was not present in testes in which the Leydig cells had been destroyed, but it could be induced by a low dose of testosterone. Transposition of a scrotal testis into the abdominal cavity inhibited vasomotion and this was apparently not caused by Leydig cell malfunction. Depletion of specific germ cells (by unilateral $\mathrm{X}$-irradiation induced killing of spermatogonia and maturation depletion of germ cells) did not abolish vasomotion in the testis. It is suggested that testicular vasomotion is influenced by testosterone and by factors from Sertoli cells.
\end{abstract}

\section{Introduction}

Vasomotion, spontaneous rhythmical variations in arteriolar blood flow, is observed in several tissues (Intaglietta, 1988) including rat testes (Damber et al., 1982, 1986). Vasomotion is probably caused by spontaneous myogenic activity in arterioles. This activity can be modulated by hormonal and neuronal factors, but the role and physiological control of vasomotion is largely unknown (Funk and Intaglietta, 1983; Intaglietta, 1988). Transvascular fluid exchange and vascular resistance can be modulated by influencing vasomotion. During periods of high flow, plasma is filtered out from the vasculature and returns during periods of slow flow. Vascular resistance is decreased when vasomotion amplitude is increased (Intaglietta, 1988).

In the rat testis, vasomotion is developmentally and hormonally controlled (Damber et al., 1986, 1990; Widmark et al., 1986, 1989). It is not present in prepubertal animals, and it is inhibited by treatment with large doses of luteinizing hormone $(\mathrm{LH})$ or human chorionic gonadotrophin ( $\mathrm{hCG}$ ) and by local administration of catecholamines (Damber et al., 1982). Vasomotion disappears if the Leydig cells are destroyed by ethane dimethyl sulfonate (EDS) treatment and it can be restored by high doses of testosterone (Damber et al., 1992), but it is not known whether local factors other than testosterone are of importance. The physiological role of vasomotion in the testis is unknown, but the relative haematocrit in testicular capillaries fluctuates in phase with vasomotion (Damber et al., 1986) and inhibition of vasomotion with LH or hCG is associated with an increase in the amount of interstitial fluid in the organ (Widmark et al., 1986, 1989) indicating that it may influence transvascular fluid exchange as in other organs (Intaglietta, 1988). The protein concentration is similar in testicular interstitial fluid and plasma and, thus, there is almost no oncotic osmotic pressure opposing capillary pressure. Transvascular fluid exchange must therefore be particularly influenced by changes in pressure in the testis (Setchell, 1990; Sweeney et al., 1991).

${ }^{*}$ Correspondence: Dr A. Bergh at the Department of Pathology.

Received 22 January 1992.
The aim of this study was therefore to elucidate the mechanisms involved in the control of testicular vasomotion.

\section{Materials and Methods}

\section{Experiment 1}

Adult male Sprague-Dawley rats (350-450 g) were given a single intraperitoneal injection of ethane dimethane sulfonate (EDS; $75 \mathrm{mg} \mathrm{kg}^{-1}$ body weight) as described by Damber $e$ al . (1987). EDS treatment results in the destruction of the Leydig cells in the testis, but other testicular cells are initially unaffected (Sharpe ef al., 1990). On day 6, the rats were assigned to five groups. Testosterone esters (Sustanon; kindly donated by Organon, Oss, The Netherlands) were injected subcutaneously at four different doses (0.1, 1, 25 or $250 \mathrm{mg}$ ); the control group received vehicle (arachis oil) only. Twenty-four hours later the animals were anaesthetized with pentobarbital $\left(40 \mathrm{mg} \mathrm{kg}^{-1}\right)$. A scrotal incision was made to expose the testes. Testicular blood flow was studied in two different areas (devoid of large vessels) on the testicular surface using laser Doppler flowmetry (Periflux 3: Perimed, Stockholm) as described by Damber et al. (1986). The blood flow signal (volts) was recorded on an electrostatic recorder for at least $5 \mathrm{~min}$ on each surface area, and average flow level, vasomotion amplitude and frequency were later analysed. The testes were removed, weighed and cut into two pieces. One piece was placed in ethanol and intratesticular testosterone concentration was analysed by a radioimmunoassay as described by Damber and Bergh (1980). The sensitivity of the assay was $10 \mathrm{pg}$ when applying the $95 \%$ confidence limit. The other piece was fixed in Bouin's solution, embedded in metacrylate resin (Histo-Resin: LKB, Stockholm) and testicular morphology examined using $2 \mu \mathrm{m}$ thick sections stained with haematoxylin-eosin.

\section{Experiment 2}

Adult male Sprague-Dawley rats $(350-450 \mathrm{~g})$ were anaesthetized with pentobarbital ( $40 \mathrm{mg} \mathrm{kg}^{-1}$ body weight) and the left 
Table 1. Effect of testosterone in rats in which the Leydig cells have been destroyed

\begin{tabular}{|c|c|c|c|c|c|}
\hline & \multicolumn{5}{|c|}{ Dose of testosterone esters $(\mathrm{mg})$} \\
\hline & 0 & 0.1 & 1 & 25 & 250 \\
\hline Number of animals & 6 & 8 & 6 & 5 & 7 \\
\hline Testis weight $(\mathrm{g})$ & $1.54 \pm 0.16$ & $1.44 \pm 0.33$ & $1.42 \pm 0.07$ & $1.53 \pm 0.10$ & $1.48 \pm 0.07$ \\
\hline Concentration of testicular testosterone (ng $\mathrm{g}^{-1}$ ) & $\overline{\text { nd }}$ & $4.6 \pm 0.8$ & $8.1 \pm 1.1^{b}$ & $31.7 \pm 4.6^{c}$ & $81.0 \pm 4.2^{\mathrm{d}}$ \\
\hline Flow $(V)$ & $4.1 \pm 0.3$ & $3.8 \pm 0.4$ & $6.0 \pm 0.9^{e}$ & $7.5 \pm 1.6^{e}$ & $5.2 \pm 0.1^{\mathrm{e}}$ \\
\hline Amplitude (V) & $\overline{0}$ & $0.49 \pm 0.4^{\mathrm{a}}$ & $1.3 \pm 0.2^{\mathrm{e}}$ & $2.0 \pm 0.6^{\mathrm{e}}$ & $1.6 \pm 0.1^{\mathrm{e}}$ \\
\hline Frequency (peaks $\min ^{-1}$ ) & 0 & $6.3 \pm 0.6^{\mathrm{a}}$ & $7.2 \pm 0.4$ & $8.5 \pm 0.7$ & $8.4 \pm 0.7$ \\
\hline
\end{tabular}

Values are means \pm SEM.

nd: not detectable.

aSignificantly different from value in rats not given testosterone, $P<0.05$.

'Significantly different from value in the $0,25,250 \mathrm{mg}$ groups, $P<0.05$.

'Significantly different from value in $0,0.1,1,250 \mathrm{mg}$ group, $P<0.05$.

${ }^{d}$ Significantly different from $0,0.1,1$ and $25 \mathrm{mg}$ group, $P<0.05$.

eSignificantly different from 0 and $0.1 \mathrm{mg}$ groups $P<0.05$ but not different from the other values with the same superscript.

testis was placed in the abdominal cavity and the inguinal canal closed by sutures as described by Bergh and Damber (1984). Six days later the animals were assigned to four groups. Group 1 was injected with vehicle (arachis oil) only and group 2 with $25 \mathrm{mg}$ testosterone esters (Sustanon) subcutaneously. Groups 3 and 4 had been injected intraperitoneally with EDS (as described above) on the day of operation. Six days after the operation, group 3 received an injection of vehicle only and group 4 was injected subcutaneously with $25 \mathrm{mg}$ testosterone esters. At day 7 ( $24 \mathrm{~h}$ after injections), the animals were anaesthetized with pentobarbital ( $40 \mathrm{mg} \mathrm{kg}^{-1}$ body weight) and testicular blood flow, testosterone concentration and testicular morphology were examined in the scrotal and abdominal testes as described in Expt 1.

\section{Experiment 3}

The left testis of adult male Sprague-Dawley rats (350$450 \mathrm{~g}$ ) was irradiated with a dose of $3 \mathrm{~Gy}$ using $4 \mathrm{MeV}$ X-rays produced by a linear accelerator, as described by Kangasniemi et al. (1990). The right testis was protected by a lead shield and served as a control. $X$-irradiation of the testis at this dose results in a selective, transient depletion of cycling spermatogonia. If the testes are studied at different intervals after irradiation, they lack a particular type of germ cell as a result of maturation depletion (Kangasniemi et al., 1990). At 7, 17, 28, 45 and 56 days after irradiation, the animals were anaesthetized with pentobarbital and testicular blood flow, testosterone and morphology were examined as described above.

\section{Statistical analysis}

Comparisons among groups were made using the KruskallWallis one-way analysis of variance; for comparisons between groups, the Mann-Whitney U test and the Wilcoxon test for paired observations were used. Correlation was expressed by the Spearman rank correlation coefficient. A $P$ value less than 0.05 was considered statistically significant.

\section{Results}

\section{Experiment 1. Role of testosterone in vasomotion}

Light microscopy confirmed that Leydig cells were not present in EDS- and vehicle-treated animals. The concentration of testicular testosterone was below the detection limit of the assay. Testosterone ester treatment resulted in a dose-dependent increase in intratesticular testosterone concentration (Table I) and values equivalent to those in intact animals (see Damber and Bergh, 1980) were reached with the highest dose. There was a strong linear correlation between testosterone ester dose and intratesticular testosterone concentration $\left(r_{s}=0.94, P<0.0001\right)$. A discrete increase in the number of degenerating germ cells, particularly in tubular stage VII was noted in all treatment groups, but otherwise testicular morphology was similar to that of intact scrotal rat testes.

Vasomotion was absent in rats receiving EDS only (Fig. 1). In all rats given testosterone esters in doses from 1 to $250 \mathrm{mg}$, an almost identical vasomotion pattern (similar flow level, amplitude and frequency) was found (Table 1, Fig. 1). In rats given $0.1 \mathrm{mg}$ testosterone esters, the average blood flow signal was lower than that in rats receiving the higher doses, but vasomotion with a normal frequency but small amplitude was present (Fig. 1).

\section{Experiment 2. Effect of cryptorchidism on vasomotion}

No Leydig cells were present in the EDS-treated scrotal and abdominal testes. Cryptorchidism resulted in degenerative changes in the seminiferous epithelium in testes with or without Leydig cells and in those receiving testosterone supplement, and testicular weights were reduced (Table 2, Fig. 2). Normal vasomotion was present in scrotal testes, but in the contralateral abdominal testes a continuous flow was observed (Fig. 3). 


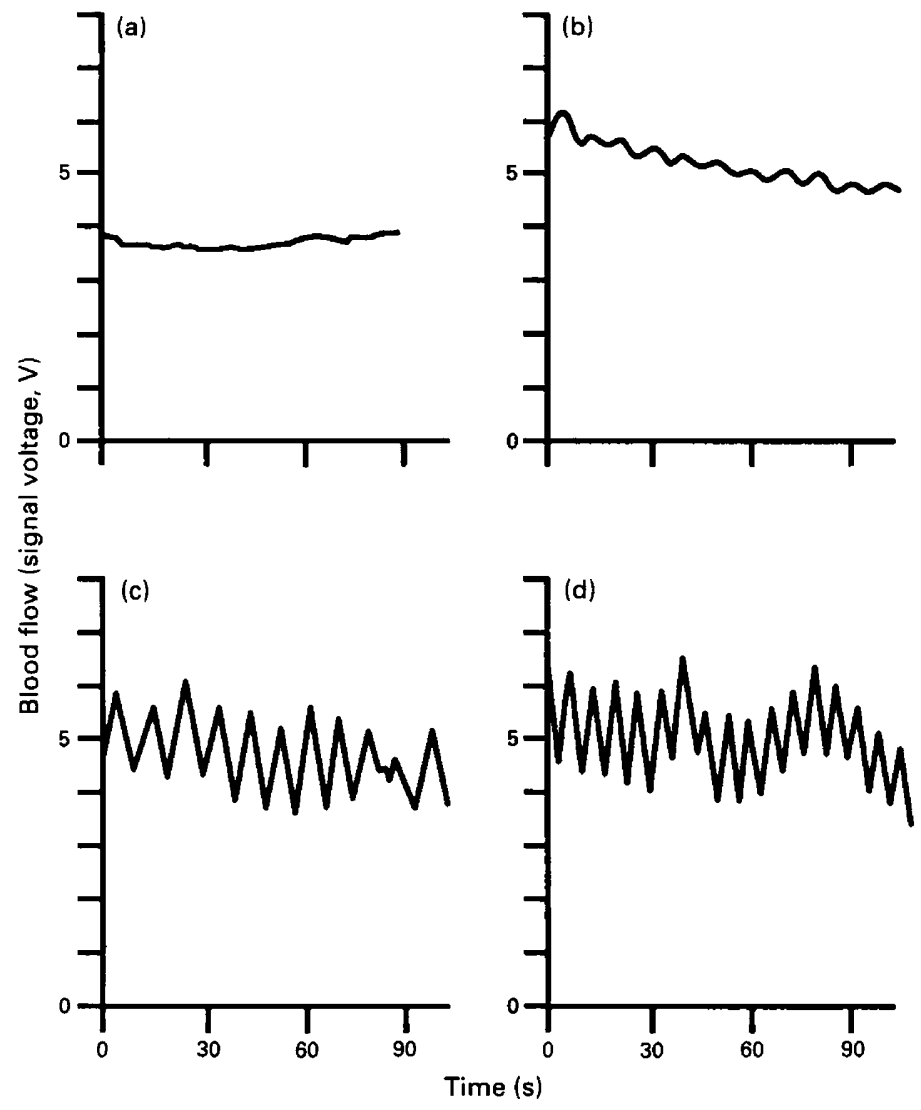

Fig. 1. Representative laser Doppler recordings of testicular blood flow in rats in which the Leydig cells have been destroyed and which had been treated with different doses of testosterone esters (TE) $24 \mathrm{~h}$ earlier (a) vehicle only; (b) $0.1 \mathrm{mg} \mathrm{TE}$; (c) $1 \mathrm{mg} \mathrm{TE}$; (d) $250 \mathrm{mg}$ TE.

Table 2. Effects of surgically induced unilateral cryptorchidism in adult rats 7 days after operation

\begin{tabular}{|c|c|c|c|c|c|c|}
\hline Treatment & $\begin{array}{l}\text { Position } \\
\text { of testis }\end{array}$ & $\begin{array}{c}\text { Testis } \\
\text { weight } \\
(g)\end{array}$ & $\begin{array}{l}\text { Concentration } \\
\text { of testicular } \\
\text { testosterone } \\
\left(\mathrm{ng} \mathrm{g}^{-1}\right)\end{array}$ & $\begin{array}{l}\text { Flow } \\
(\mathrm{V})\end{array}$ & $\begin{array}{l}\text { Vasomotion } \\
\text { amplitude } \\
\text { (V) }\end{array}$ & $\begin{array}{l}\text { Vasomotion } \\
\text { (peaks } \min ^{-1} \text { ) }\end{array}$ \\
\hline \multirow[t]{2}{*}{ Vehicle only $(n=5)$} & Scrotal & $1.96 \pm 0.04$ & $150 \pm 86$ & $4.0 \pm 0.8$ & $0.8 \pm 0.2$ & $7.4 \pm 0.4$ \\
\hline & Abdominal & $0.89 \pm 0.05^{\mathrm{a}}$ & $56 \pm 12$ & $4.8 \pm 1.4$ & $\overline{0}$ & $\overline{0}$ \\
\hline \multirow[t]{2}{*}{ Testosterone esters $(n=5)$} & Scrotal & $1.82 \pm 0.11$ & $64 \pm 20$ & $4.8 \pm 1.1$ & $1.1 \pm 0.2$ & $7.4 \pm 0.4$ \\
\hline & Abdominal & $0.90 \pm 0.11^{a}$ & $77 \pm 23$ & $5.0 \pm 0.9$ & $\overline{0}$ & $\overline{0}$ \\
\hline \multirow[t]{2}{*}{$\operatorname{EDS}(n=5)$} & Scrotal & $1.52 \pm 0.24$ & nd & $3.6 \pm 0.7$ & 0 & 0 \\
\hline & Abdominal & $0.69 \pm 0.08^{\mathrm{a}}$ & nd & $5.2 \pm 1.8$ & 0 & 0 \\
\hline \multirow[t]{2}{*}{ EDS + testosterone esters $(n=5)$} & Scrotal & $1.54 \pm 0.14$ & $40 \pm 10$ & $4.9 \pm 1.6$ & $1.0 \pm 0.3$ & $6.5 \pm 0.5$ \\
\hline & Abdominal & $0.75 \pm 0.09^{\mathrm{a}}$ & $80 \pm 32$ & $5.9 \pm 2.0$ & $\overline{0}$ & $\overline{0}$ \\
\hline
\end{tabular}

Values are means \pm SEM.

nd: not detectable.

$n=$ number of animals; EDS: ethane methyl sulfonate.

'Significantly different from the value in the scrotal testis, $P<0.05$.

Treatment with testosterone esters did not influence the blood flow pattern in scrotal or in abdominal testes. EDS treatment inhibited vasomotion in the scrotal testes, but it could be res- tored with testosterone ester treatment (Fig. 3). Blood flow was continuous in abdominal testes of EDS-treated animals and this was not influenced by testosterone supplementation (Fig. 3). 


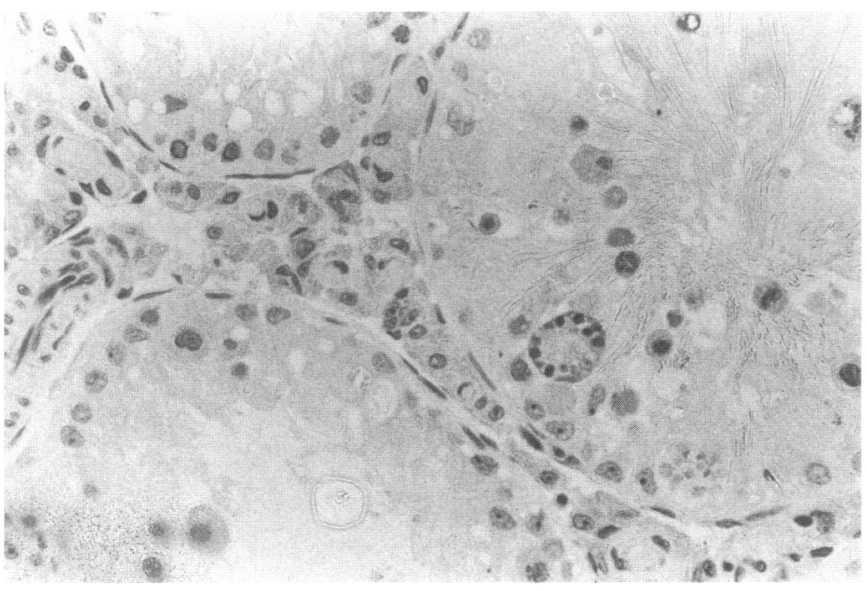

Fig. 2. Section from the abdominal testis of a unilaterally cryptorchid rat $(\times 270)$. The seminiferous tubules have an abnormal morphology; some lack differentiated germ cells and others contain abnormal and giant spermatids. No apparent morphological changes are observed in blood vessels or in the Leydig cells. Vasomotion was not present in this testis.

\section{Experiment 3. Role of different types of germ cell in vasomotion}

Local irradiation of the left testis resulted in depletion of spermatogonia but spermatogenesis in the contralateral testis was unaffected.

At different times after treatment the irradiated testes showed tubules where different types of germ cell were missing (summarized in Table 3, Fig. 4) and as described in detail previously by Kangasniemi et al. (1990). Testicular testosterone concentrations were similar in the control and irradiated testes at all study points except at 56 days (Table 3). Depletion of germ cells by irradiation did not at any time induce clear change in testicular vasomotion compared with that in control testes (Table 3, Fig. 5). At 7, 17 and 28 days, the blood flow recordings were identical in the irradiated and in the contralateral control testes in all animals. At 38,45 and 56 days, the irradiated testes showed vasomotion but the pattem was more irregular than in the contralateral normal testes in 4 of 9,2 of 5,4 of 6 of the examined animals, respectively (Fig. 5). In the other animals examined at 38,45 or 56 days, normal vasomotion was seen in the irradiated testes. This difference in response could not be explained by the morphology of the individual testes: they all showed a similar extent of germ cell depletion.

\section{Discussion}

This study confirms that a high dose of testosterone can restore normal vasomotion to the testes of rats in which the Leydig cells have been destroyed (Damber et al., 1992). However, considerably less testosterone is apparently needed, since vasomotion was restored, although with a smaller amplitude, when the concentration of testicular testosterone was about $5 \mathrm{ng} \mathrm{g}^{-1}$, that is about $5 \%$ of the normal value in adult rats (Damber and Bergh, 1980). An apparently normal flow can be induced by a dose of $1 \mathrm{mg}$ testosterone esters. This dose is known to normalize serum testosterone, but it does not normalize intratesticular
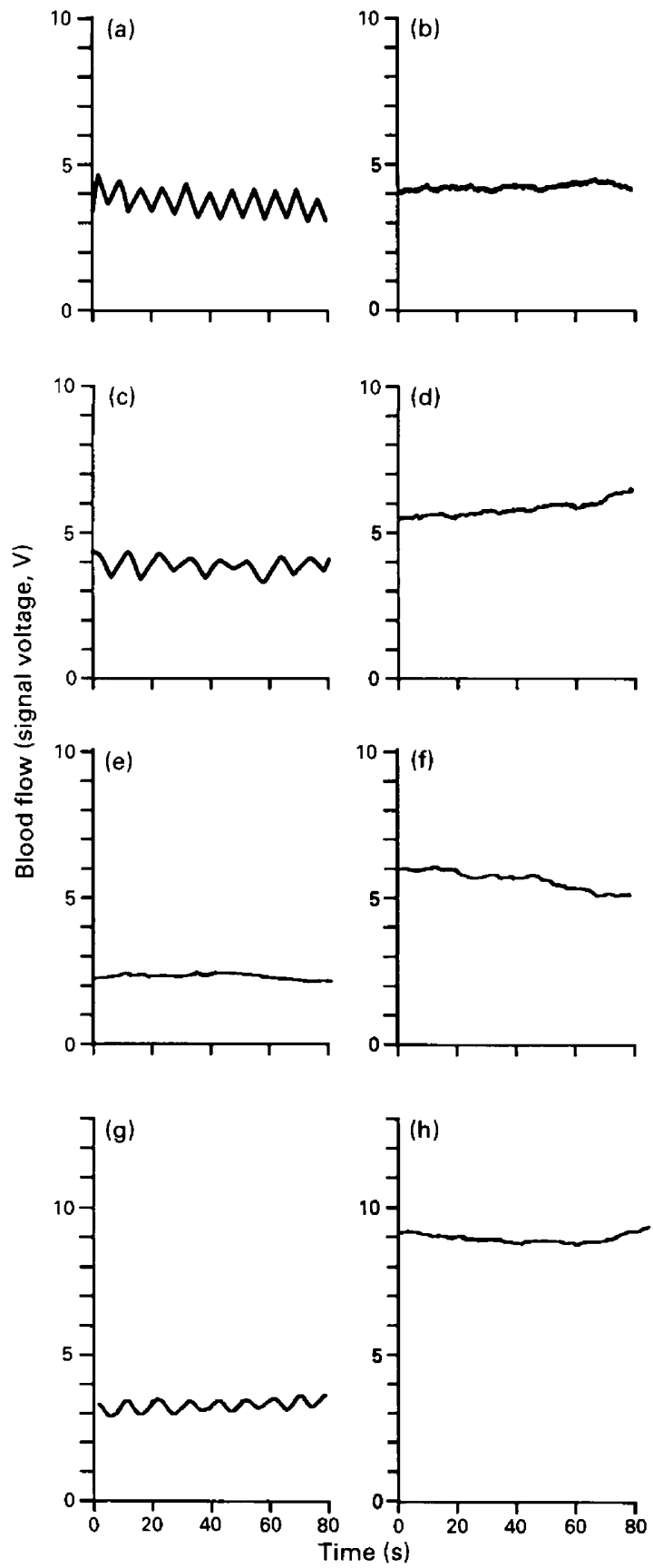

Fig. 3. Representative laser Doppler recordings of testicular blood flow in scrotal $(a, c, e, g)$ and abdominal testes $(b, d, f, h)$ in rats that have been unilaterally cryptorchid for 7 days and that received the following additional treatments. ( $a, b)$ No further treatment; (, d) $25 \mathrm{mg}$ testosterone esters on day $6 ;(e, f)$ ethane methyl sulfonate (EDS) on day $0 ;(\mathrm{g}, \mathrm{h})$ EDS on day 0 and $25 \mathrm{mg}$ testosterone esters on day 6.

testosterone or spermatogenesis (Sharpe et al., 1990). The mechanism by which testosterone may induce vasomotion (myogenic activity in small arterioles) is unknown (see below). This study suggests that vasomotion, when induced by low concentrations of testosterone in testes in which the Leydig cells have been destroyed, is of the same frequency as in intact 
Table 3. Effects of unilateral testicular irradiation in rats

\begin{tabular}{|c|c|c|c|c|c|c|c|c|}
\hline $\begin{array}{l}\text { Time after } \\
\text { irradiation } \\
\text { (days) }\end{array}$ & Testis & $\begin{array}{l}\text { Number } \\
\text { of } \\
\text { animals }\end{array}$ & $\begin{array}{l}\text { Weight of } \\
\text { testis } \\
\text { (g) }\end{array}$ & $\begin{array}{l}\text { Testosterone } \\
\text { concentration } \\
\left(\mathrm{ng} \mathrm{g}^{-1}\right)\end{array}$ & Germ cells depleted & $\begin{array}{c}\text { Flow } \\
\text { (V) }\end{array}$ & $\begin{array}{l}\text { Vasomotion } \\
\text { amplitude } \\
\text { (V) }\end{array}$ & $\begin{array}{l}\text { Vasomotion } \\
\text { frequency } \\
\text { (peaks } \min ^{-1} \text { ) }\end{array}$ \\
\hline \multirow[t]{3}{*}{7} & & 5 & & & & & & \\
\hline & c & & $2.00 \pm 0.09$ & $129 \pm 47$ & none & $5.9 \pm 0.4$ & $0.9 \pm 0.1$ & $10.0 \pm 0.4$ \\
\hline & $\mathrm{i}$ & & $1.94 \pm 0.01^{\mathrm{a}}$ & $120 \pm 30$ & spermatogonia & $4.9 \pm 0.6$ & $1.1 \pm 0.3$ & $9.4 \pm 0.4$ \\
\hline \multirow[t]{3}{*}{17} & & 5 & & & & & & \\
\hline & c & & $2.01 \pm 0.06$ & $117 \pm 21$ & none & $6.6 \pm 0.7$ & $1.1 \pm 0.2$ & $9.6 \pm 0.8$ \\
\hline & $\mathrm{i}$ & & $1.79 \pm 0.05^{\mathrm{a}}$ & $99 \pm 23$ & $\begin{array}{l}\text { spermatogonia, } \\
\text { pachytene spermatocytes }\end{array}$ & $5.6 \pm 0.5$ & $1.1 \pm 0.2$ & $9.0 \pm 0.4$ \\
\hline \multirow[t]{3}{*}{28} & & 5 & & & & & & \\
\hline & c & & $1.94 \pm 0.06$ & $129 \pm 20$ & none & $6.5 \pm 0.5$ & $1.1 \pm 0.1$ & $8.8 \pm 0.4$ \\
\hline & $\mathrm{i}$ & & $1.49 \pm 0.05^{\mathrm{a}}$ & $148 \pm 26$ & $\begin{array}{l}\text { primary spermatocytes, } \\
\text { round spermatids }\end{array}$ & $5.2 \pm 0.6$ & $1.1 \pm 0.2$ & $7.4 \pm 0.9$ \\
\hline \multirow[t]{3}{*}{38} & & 9 & & & & & & \\
\hline & c & & $1.97 \pm 0.05$ & $85 \pm 10$ & none & $5.3 \pm 0.2$ & $0.8 \pm 0.1$ & $9.7 \pm 0.6$ \\
\hline & $\mathrm{i}$ & & $1.15 \pm 0.05^{\mathrm{a}}$ & $80 \pm 14$ & $\begin{array}{l}\text { pachytene spermatocytes, } \\
\text { round spermatids }\end{array}$ & $5.2 \pm 0.2$ & $0.7 \pm 0.1$ & $9.2 \pm 0.3$ \\
\hline \multirow[t]{3}{*}{45} & & 5 & & & & & & \\
\hline & c & & $2.05 \pm 0.03$ & $216 \pm 84$ & none & $7.3 \pm 0.4$ & $1.3 \pm 0.1$ & $9.0 \pm 0.3$ \\
\hline & $\mathrm{i}$ & & $1.12 \pm 0.05^{\mathrm{a}}$ & $184 \pm 47$ & round mature spermatids & $7.1 \pm 1.0$ & $1.5 \pm 0.5$ & $7.4 \pm 0.7^{\mathrm{a}}$ \\
\hline \multirow[t]{3}{*}{56} & & 6 & & & & & & \\
\hline & c & & $1.93 \pm 0.05$ & $88 \pm 21$ & none & $6.3 \pm 0.3$ & $1.5 \pm 0.1$ & $9.6 \pm 0.2$ \\
\hline & $\mathrm{i}$ & & $1.29 \pm 0.06^{\mathrm{a}}$ & $107 \pm 18^{\mathrm{a}}$ & mature spermatids & $6.2 \pm 0.7$ & $1.4 \pm 0.2$ & $10.0 \pm 0.3$ \\
\hline
\end{tabular}

Values are means \pm SEM.

c: control; i: irradiated testis.

'Significantly different from that in the contralateral testis, $P<0.05$.

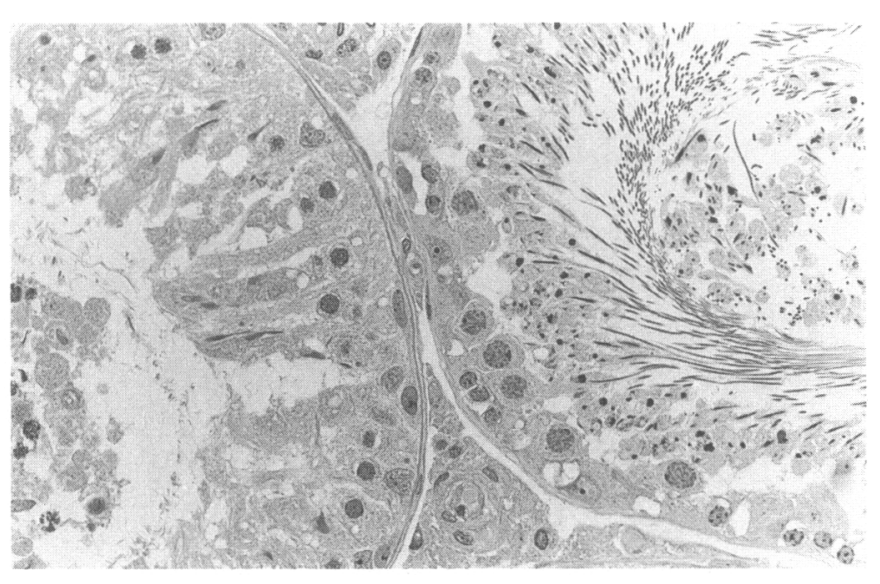

Fig. 4. Section from a testes irradiated 38 days earlier $(\times 270)$. The numbers of round spermatids and pachytene spermatocytes are reduced. There are no apparent morphological changes in the blood vessels or in the Leydig cells. Vasomotion was normal in this testis.

testes. It appears that slightly more testosterone is required to normalize vasomotion amplitude than vasomotion frequency. The observation that an apparently normal flow can be induced by very low concentrations of testosterone suggests that testicular vasomotion is not regulated by moderate physiological reductions in testosterone concentration in the testis.

We have previously demonstrated that vasomotion is not present in 20-day-old prepubertal animals (Damber et al., 1990).
At this age, the concentration of testicular testosterone is about $15 \mathrm{ng} \mathrm{g}^{-1}$ and scrotal development is not complete (Bergh et al., 1987). Vasomotion is inhibited in abdominal testes in this study, and we showed that this is not related to Leydig cell dysfunction or reduced intratesticular testosterone concentration. Vasomotion does not disappear until several days after transposition of an adult testis into the abdomen (Hjertkvist et al., 1988). Long-term cryptorchidism results in altered vascular morphology (see Bergh, 1989 for review), but a low amplitude, low frequency vasomotion is still present in adult testes that have been lying in the abdomen since birth (Hjertkvist et al., 1988). Thus, the lack of vasomotion in prepubertal and the 7 day abdominal testes in this study cannot be explained by insufficient testosterone or by direct effect of temperature or cryptorchidism on the vasculature. Other factors must therefore be important.

One possible source for a factor modulating testicular vasomotion would be the seminiferous tubules. When testosterone is given to rats with testes without Leydig cells, it probably influences the seminiferous tubules, since androgen receptors are known to be present on peritubular and Sertoli cells (Sharpe et al., 1990, see below). A general stimulation of tubule metabolism, or the induction of a specific testosterone-dependent factor, are possible reasons for the vascular effects of testosterone in these animals. It is, however, not known to what extent an extremely low concentration of intratesticular testosterone (hardly detectable) influences tubule metabolism. Using immunohistochemistry, we have recently observed androgen receptors in the 


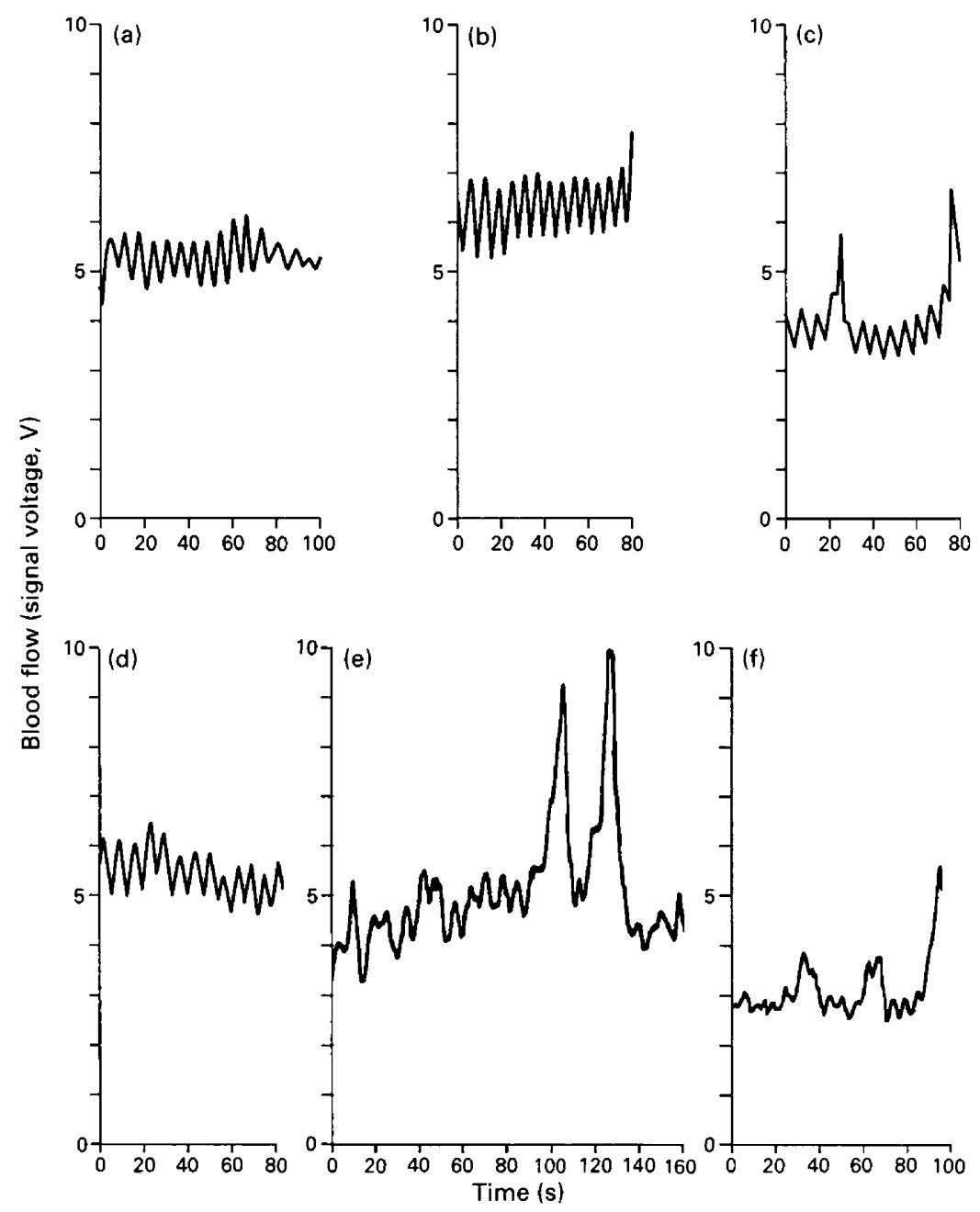

Fig. 5. Representative laser Doppler recordings of testicular blood flow in testes irradiated at different times prior to study (a) 7 days; (b) 17 days; (c) 38 days; (d) 45 days; (e) 45 days; (f) 56 days.

muscular layer of small arteries in scrotal and abdominal testes (Bergh and Damber, 1992). The present observation that a very low dose of systemically administered testosterone esters induces vasomotion suggests a direct effect of androgens on blood vessels. However, testosterone did not induce vasomotion in testes with tubule damage induced by cryptorchidism. Cryptorchidism results in altered Sertoli cell function and in degeneration of primary spermatocytes and spermatids; some studies suggest that the primary effect of increased temperature is Sertoli cell malfunction. There are as yet no indications of altered vascular morphology after 7 days of cryptorchidism (see Bergh, 1989 for review). The inhibited vasomotion in 7-day cryptorchid testes could thus suggest that Sertoli cells or germ cells are involved in modulating testicular vasomotion. The data from the irradiation experiments indicate that a particular germ cell type is not critically necessary for normal vasomotion, although an irregular pattern was often observed after depletion of spermatids. Sertoli cell function is influenced by adjacent germ cells; some germ cells stimulate, whereas others inhibit, Sertoli cells (Jegou et al., 1988; Allenby et al., 1991). Sharpe et al. (1991) showed that selective depletion of late spermatids resulted in an increase in the volume of interstitial fluid in the testis (volume of interstitial fluid is influenced by changes in blood flow and vascular permeability, see Bergh et al., 1988) and suggested that the altered function of Sertoli cells could via paracrine effects influence the vasculature. Collectively, available data thus indicate that the lack of vasomotion in cryptorchid testes could be related to impaired Sertoli cell function, and that these Sertoli cells cannot secrete the factors necessary for normal vasomotion. However, direct cryptorchidism or temperatureinduced effects on the vasculature cannot be ruled out.

Previous studies have shown that Leydig cells play a key role in the regulation of testicular blood flow and vasomotion (Bergh et al., 1988). We suggest that part of this effect could be mediated directly via vascular androgen receptors but that testosterone-dependent Sertoli cell products are also involved. The nature of these postulated products of Sertoli cells are unknown.

This study was supported by grants from the Swedish Medical Research Council (project no. 5935) and the Maud and Birger Gustavsson Foundation. 


\section{References}

Allenby G, Foster PMD and Sharpe RM (1991) Evidence that secretion of immunoreactive inhibin by seminiferous tubules is regulated by specific germ cell types: correlation between in-vivo and in-vitro studies Endocrinology 128 $467-476$

Bergh A (1989) Experimental models of cryptorchidism. In The Cryptorchid Testis pp 15-34 Eds B Keel and T Abney. CRC Press, Boca Raton

Bergh A and Damber J-E (1984) Local regulation of Leydig cells from the seminiferous tubules - effect of short-term cryptorchidism International Journal of Andrology 7 409-418

Bergh A and Damber J-E (1992) Immunohistochemical demonstration of androgen receptors in testicular blood vessels Intemational Journal of Andrology 15 425-434

Bergh A, Damber J-E and Huhtaniemi I (1987) Intratesticular steroids and gonadotrophin receptor concentrations in the testes of immature unilaterally cryptorchid rats International Joumal of Andrology $10803-808$

Bergh A, Damber J-E and Widmark A (1988) Hormonal control of testicular blood flow, microcirculation and vascular permeability. In The Molecular and Cellular Endocrinology of the Testis, Serono Symposia Vol. 50 pp 123-134 Eds BA Cooke and RM Sharpe. Raven Press, NY

Damber J-E and Bergh A (1980) Decreased testicular response to acute LHstimulation and increased intratesticular concentration of oestradiol-17 $\beta$ in the abdominal testes in cryptorchid rats Acta Endocrinologica 95 416-421

Damber J-E, Lindahl O, Selstam G and Tenland T (1982) Testicular blood flow measured with a laser Doppler flowmeter: acute effects of catecholamines Acta Physiologica Scandinavia 115 209-215

Damber J-E, Bergh A, Fagrell B, Lindahl O and Rooth P (1986) Testicular microcirculation in the rat studied by videophotometric capillaroscopy, fluorescence microscopy and laser doppler flowmetry Acta Physiologica Scandinavia 126 371-376

Damber J-E, Bergh A and Widmark A (1987) Testicular blood flow and microcirculation in rats after treatment with ethane dimethyl sulfonate (EDS) Biology of Reproduction 37 1291-1296

Damber J-E, Bergh A and Widmark A (1990) Age-related differences in testicular microcirculation International Journal of Andrology 13 197-206

Damber J-E, Maddocks S, Widmark A and Bergh A (1992) Testicular blood flow and vasomotion can be maintained by testosterone in Leydig cell-depleted rats International journal of Andrology 15 385-393
Funk W and Intaglietta M (1983) Spontaneous arteriolar vasomotion Progress in Applied Microcirculation 3 66-82

Hjertkvist M, Bergh A and Damber J-E (1988) HCG treatment increases intratesticular pressure in abdominal testes in unilaterally cryptorchid rats Journal of Andrology 9 116-121

Intaglietta M (1988) Arteriolar vasomotion: normal physiological activity or defence mechanism Diabetes and Metabolism 14 489-494

Jegou B, Le Magueresse B, Sourdaine P, Pineau C, Velez de la Calle JF, Garnier DH, Guillou F and Boisseau C (1988) Germ cell-Sertoli cell interactions in vertebrates. In The Molecular and Cellular Endocrinology of the Testis Serono Symposia Vol. 50 pp 255-270 Eds BA Cooke and RM Sharpe. Raven Press, NY

Kangasniemi MK, Veromaa T, Kulmala J, Kaipia A, Parvinen M and Toppari J (1990) DNA flow cytometry defined stages of rat seminiferous epithelium: effects of 3 Gy high-energy X-irradiation Joumal of Andrology 11 312-317

Maddocks S and Sharpe RM (1989) Interstitial fluid volume in the rat testisandrogen-dependent regulation by the seminiferous tubules? Journal of Endocrinology $120215-222$

Setchell BP (1990) Local control of testicular fluids Reproduction, Fertility and Development 2 291-309

Sharpe RM, Maddocks S and Kerr JB (1990) Cell-cell interactions in the control of spermatogenesis as studied using Leydig cell destruction and testosterone replacement American Joumal of Anatomy 188 3-20

Sharpe RM, Bartlett JMS and Allenby G (1991) Evidence for the control of testicular interstitial fluid volume in the rat testis by specific germ cell types Joumal of Endocrinology 128 359-367

Sweeney TE, Rozum JS, Desjardins C and Gore RW (1991) Microvascular pressure distribution in the hamster testis American Journal of Physiology 260 H1581-H1589

Widmark A, Damber J-E and Bergh A (1986) Relationship between human chorionic gonadotrophin-induced changes in testicular microcirculation and the formation of testicular interstitial fluid Joumal of Endocrinology 109 419-425

Widmark A, Damber J-E and Bergh A (1989) High and low doses of luteinizing hormone induce different changes in testicular microcirculation Acta Endocrinologica $121621-627$ 